\title{
Biofloc contribution to antioxidant defence status, lipid nutrition and reproductive performance of broodstock of the shrimp Litopenaeus stylirostris: Consequences for the quality of eggs and larvae
}

\author{
Cardona Emilie ${ }^{1,2, *}$, Lorgeoux Bénédicte ${ }^{1}$, Chim Liet ${ }^{2}$, Goguenheim Jean ${ }^{1}$, Le Delliou Hervé ${ }^{3}$, \\ Cahu Chantal $^{3}$
}

${ }^{1}$ IFREMER, Centre Océanologique du Pacifique, Unité de recherche Ressources Marines, B.P 7004, 98719 Taravao, French Polynesia

2 IFREMER, Unité de recherche Lagons, Ecosystèmes et Aquaculture Durable en Nouvelle Calédonie B.P. 2059, 98846 Nouméa, New Caledonia

${ }^{3}$ IFREMER, Centre de Brest, Physiologie Fonctionnelle des Organismes Marins, UMR 6539 LEMAR, 29280 Plouzane, France

*Corresponding author : Emilie Cardona, email addresses : emilie.cardona@ifremer.fr ; emiliecardona2@gmail.com

\begin{abstract}
:
The aim of this study was to determine biofloc contributions to the antioxidant status and lipid nutrition of broodstock of Litopenaeus stylirostris in relationship with their reproductive performance and the health of larvae produced. Shrimp broodstock reared with Biofloc technology (BFT) compared to Clear water (CW) exhibited a higher health status with (i) a better final survival rate during the reproduction period (52.6\% in CW against $79.8 \%$ in BFT); (ii) higher glutathione level (GSH) and total antioxidant status (TAS), reduced oxidized/reduced glutathione ratio and a higher spawning rate and frequency as well as higher gonado-somatic index and number of spawned eggs. Finally, larvae from broodstock from BFT exhibited higher survival rates at the Zoe $2(+37 \%)$ and Post Larvae $1(+51 \%)$ stages when compared with those from females from $\mathrm{CW}$ treatment. The improved reproductive performance of the broodstock and higher larvae survival rate resulting from BFT treatment may be linked to the dietary supplement obtained by the shrimp from natural productivity during BFT rearing. Indeed, our study confirms that biofloc particulates represent a potential source of dietary glutathione and a significant source of lipids, particularly essential phospholipids and n-3 highly unsaturated fatty acids (HUFA) for shrimps. Thus, broodstock from BFT treatment accumulated phospholipids, n-3 HUFA and arachidonic acid, which are necessary for vitellogenesis, embryogenesis and pre-feeding larval development. The predominant essential fatty acids, arachidonic acid (ARA), eicopentaeonic acid (EPA) and docosahexaenoic acid (DHA), had levels in the eggs that were, respectively, 2.5, 2.8 and 3 fold higher for BFT compared to the CW treatment.
\end{abstract}


Statement of Relevance

Today, the influence of biofloc technology on shrimp broodstock is not enough described and no information was available on the larvae quality.

Moreover, two key pieces of new information emerge from the present study. Firstly, biofloc is a source of further dietary lipids that can act as energetic substrates, but also as a source of phospholipids and essential fatty acids necessary to sustain reproduction, embryonic and larval development. Second, improving the reproduction of the broodstock also leads to an improvement in the quality of the larvae.

We think that our research is new and important to increase knowledge on biofloc topic. We believe the paper will contribute to the development of more efficient and therefore more sustainable systems.

\section{Highlights}

- Biofloc technology (BFT) compared to Clear water (CW) breeding improved the antioxidant status of shrimps. BFT enhanced the reproductive performance of broodstock and shrimp larvae survival. Biofloc particulates represent a potential source of dietary glutathione and a significant source of lipids, particularly phospholipids and n-3 highly unsaturated fatty acids necessary to sustain reproduction, embryonic and larval development.

Keywords: Biofloc technology, Shrimp broodstock culture, Litopenaeus stylirostris, reproductive performance, antioxidant defences, fatty acids, larval survival 


\section{Introduction}

Biofloc Technology (BFT) is a breeding system with zero or minimal water exchange. In this system, the development of aggregates of microbes such as bacteria, microalgae, protozoa and others, along with detritus including organic particles, takes place in the water column (Avnimelech, 2009). The resulting aggregates or biofloc of the microbial community present in this system contribute to maintaining the rearing water's quality and can be used as a nutrient source for the shrimp (Burford et al., 2004; Avnimelech, 2009).

Since the turn of the century, many studies have been carried out on biofloc culture of peneid shrimps (Avnimelech, 2009). Most authors agree that biofloc particulates contribute as a natural food for the shrimps and lead to lower apparent protein requirements and feed pellet conversion ratios (Browdy et al., 2001; Wasielesky et al., 2006; Schneider et al., 2005; Hargreaves, 2006). In addition, growth and the survival rates are improved when the shrimps are reared with BFT (Epp et al., 2002; Tacon et al., 2002; Burford et al., 2004). Biofloc technology has been used to rear shrimp intensively in Tahiti since the 1980s (Aquacop, 1984) but its application to broodstock rearing started more recently in 2006 in Tahiti and New Caledonia (Chim et al., 2010). These authors showed that reproductive performances of L. stylirostris broodstock from BFT were dramatically improved compared to those reared extensively in an earthen pond. This improvement in reproduction could be explained by the extra dietary energy from biofloc aggregates allowing the shrimps to produce more eggs and spawn more frequently. In addition, several studies have shown that biofloc is consumed by the shrimp and provides growth-enhancing factors as well as a significant fraction of the overall protein demand (Burford et al., 2004; Crab et al., 2010, Wasielesky et al., 2006; Xu et al., 2012). Other studies have shown that dietary biofloc could enhance the cellular immune response and antioxidant status of cultured shrimp, probably because it is rich in natural microorganisms and bioactive compounds (Ju et al., 2008; Xu and Pan, 2013). Many authors determined that biofloc particles are a potential source of lipids and fatty acids that could contribute to juvenile shrimp nutrition (Crab et al., 2010; Shyne Anand et al., 2014). Moreover, several studies have shown that dietary biofloc could enhance the immune cellular response and antioxidant status of cultured shrimp, probably because it is rich in natural microorganisms and bioactive compounds (Ju et al., 2008; Xu and Pan, 2013). In the same way, numerous researches have noted that shrimp are healthiest and grow best in aquaculture systems that have high levels of algae, bacteria and other 
natural biota (Avnimelech, 2009; Kuhn et al., 2009). Dietary supplements made by the biofloc, and its role in the health of animals, most likely contribute to the welfare of the shrimp.

However, the nutritional contribution of biofloc to the reproductive performance, quality of eggs and early larval stage of peneid shrimps is poorly documented. The prime factors that could cause differences in reproductive performance and the success of embryonic development are the physiological and nutritional status of the female (Palacios et al., 1998; Luo et al., 2008). Moreover, the relationship between broodstock and offspring quality is often suspected insofar as the vitellus of penaeid shrimp eggs must entirely support the development of the embryo and the first larval stages (nauplius) until molting into a "first-feeding" larvae (Zoe1) (Harrison, 1990). Indeed, the embryo and pre-feeding larvae of peneaid shrimps are lecitotrophic, as their nutrition is solely supplied by egg yolk reserves. The quality and quantity of nutrients in the egg yolk is dependent on maternal body reserves, the capacity for biosynthesis, and dietary intake during maturation (Harrison, 1990). Lipids that provide energy as well as essential nutrients, such as phospholipids (PLS) and essential fatty acids, are believed to be key nutritional factors influencing the reproductive process, egg hatching rate and larval survival of peneid shrimps (Teshima et al., 1989; Cahu et al., 1994; Xu et al., 1994).

In this context, the aim of the present study is to assess the biofloc contribution to the antioxidant status and lipid nutrition of $L$. stylirostris broodstock in relationship to their reproductive performance, egg lipids composition and the health of their larvae.

\section{Material and methods}

\subsection{Experimental shrimps}

The L. stylirostris shrimps used in our experiments came from a single population of post-larvae produced in the hatchery that were reared semi-intensively (without aeration) in earthen ponds ( 8 PL. $\mathrm{m}^{-2}$ ) at the Aquaculture Technical Centre of Tahiti (French Polynesia).

\subsection{Broodstock grow-out systems and experimental design}

At the end of the growth period in earthen ponds, 1800 adult L. stylirostris (mean weight $40.6 \pm$ $0.67 \mathrm{~g}$ ) were fished out and transferred into six $25 \mathrm{~m}^{3}$ circular polyethylene tanks where they were reared under the same conditions for one week (acclimatization period) prior to beginning the experiment. Each tank was equipped with central aeration to uniform aeration to maintain normoxia in the water column. The water exchange rate was 200\% daily. Each tank was stocked with 12 animals. $\mathrm{m}^{-2}$. Shrimps were fed using an automatic feeder, $3 \%$ of their estimated biomass daily, with 
commercial feed (Grower 40, SICAC; Crude protein: 39.5\%; Crude fat: 7.9\%; Crude fibre: 2.8\%; Ash: 13.9\%; Moisture: 10.7\%; C 20:5: 0.5\%; C22:6: 0.4\%).

After this week of acclimatization, tanks were assigned to two different treatments during 10 weeks: Clear Water (CW) and BioFloc Technology (BFT); each treatment was carried out in triplicate ( $n=3$ tanks). In our study, the experimental unit is therefore represented by the tank.

CW management - the broodstock culture in clear water management was carried out in the same way as during the acclimatization period of the animals (see above). The turnover rate of the water was kept high ( $200 \%$ daily) in order to eliminate organic matter from the rearing volume.

BFT management - the BFT used for this study was developed by Aquacop team in Tahiti (Aquacop, 1984). In this experiment, all rearing parameters were kept identical to those in the CW treatment except the renewal rate of the water and the provision of molasses (SICA C) as a carbon source from cane sugar to increase the C: $\mathrm{N}$ ratio. Thus, the daily water renewal was only $3 \%$ of the tank volume, mainly for removing deposits of excess organic matter (ecdysis, dead animals, unconsumed pellets...). Molasses was added daily to maintain a C:N ratio of 20:1 in order to promote the development of heterotrophic bacteria (Avnimelech, 2009). The calculation takes into account the quantity of food distributed, the nitrogen content in feed and the rate of nitrogen excretion by the shrimp.

\subsection{Water quality monitoring}

Temperature and dissolved oxygen were recorded twice per day (08:00 am and 03:00 pm) with an OxyGard Handy Gamma. The pH was recorded once per day (08:00 am) with a pH meter (Hach Lange $\mathrm{HQ} 40 \mathrm{D})$. Furthermore, total ammonia nitrogen (TAN) and nitrite-nitrogen $\left(\mathrm{NO}_{2}-\mathrm{N}\right)$ were analysed twice per week by the fluorescence method according to Holmes et al. (1999) and the spectrophotometric method according to Bendschneider and Robinson (1952), respectively. Total suspended solids (TSS) were also measured twice weekly: a water sample $(50 \mathrm{ml})$ was collected from each tank and filtered under vacuum pressure through pre-dried and pre-weighed GF/C filter paper (FW1). The filter paper containing suspended materials was dried in an oven until it attained a constant weight $\left(60^{\circ} \mathrm{C}\right.$ for $\left.24 \mathrm{~h}\right)$. Dried samples (FW2) were weighed to $0.01 \mathrm{mg}$ using a Metter AC 100 balance. TSS is the difference between FW1 and FW2. Chlorophyll a (Chl a) was determined using a spectrophotometer (Trilogy Turner Design) at wavelengths of 664 and $750 \mathrm{~nm}$, following the method of Holm-Hansen et al. (1965).

\subsection{Broodstock breeding and experimental design}


After 10 weeks in the growth phase according to the CW and BFT treatments (see §1.2), the shrimp breeders were transferred to the hatchery. Shrimps were caught in a grow-out tank using a cast net and a dip and transferred to the hatchery according to technology defined by Wabete et al. (2006). Once in the hatchery, male and female shrimps were stocked separately in circular polyethylene "maturation tanks" with a $4 \mathrm{~m}^{3}$ water capacity. Among the males, only those from BFT were kept; they were stocked in two maturation tanks at a density of 100 individuals per tank, totalling 200 animals. In contrast, females from different grow-out tanks were kept separately: each maturation tank received animals from a single corresponding grow out tank. In this way, the only treatments applied, CW and BFT, were before the transfer of broodstock into the hatchery, with 3 replicates per treatment. During the reproduction period, the experimental unit was represented by the rearing "maturation tank" ( $n=3$ for each original treatment).

Once in the hatchery all the females underwent the same breeding protocol described hereafter. Seven days after the animals were transferred to the hatchery, the females were fished out individually with a landing net to undergo unilateral eyestalk ablation (Ottogalli et al., 1988). To prevent haemorrhage, a wire ligature was used below the section. Once the operation was over, the animals were put back in their initial tank. Eyestalk ablation triggers ovarian maturation and leads the shrimps to spawn. The first females ready to spawn were observed two to three days after eyestalk ablation. They are detectable by their developed ovaries, orange/brown in colour, which are easily visible through the carapace along the dorsal part of the abdomen from the cephalothorax to the base of the telson. The state of gonad development was assessed every day by directing a light towards the animal in its tank. The mature females spawned between 11:00 am and 02:00 pm. In $L$. stylirostris, as in other open thelycum peneid species, mating occurs a few hours before spawning. In the laboratory, the males and females were kept in separate tanks and females that were ready to spawn were inseminated manually one to two hours before spawning occurred. The spermatophores were extracted by simple dorso-ventral pressure on the 5th pair of pereiopods on the male. The sperm was then extracted from the spermatophore and spread, using forceps, on the thelycum (a simple depression of the cuticle in the ventral area of the female) between the two last pair of pereiopods. The inseminated females were then placed individually in calm (without aeration) and dark spawning tanks. Right after spawning, the females were transferred back to their original tanks. The feeding regime of the broodstock in the hatchery was: fresh food twice a day (08:00 am and 04:00 pm) (mussels and squid at $9 \%$ of shrimp biomass) and commercial feed pellets once a day (01:00 pm) (at 3\% of shrimp biomass). Shrimps were fed ad libitum. The photoperiod (day/night: 14 $\mathrm{h} / 10 \mathrm{~h}$ ) was set from the first day: the spotlights above the tanks were switched on at 06:00 pm and turned off at 08:00 am. 


\subsection{Larval rearing and experimental design}

Nauplii (nii) collected from broodstock during the second and third days of the reproduction period were mixed and randomly distributed according to the original treatment (CW or BFT) given the breeders in sixteen (16) 150-L tanks at an initial stocking density of 160 nii per litre of seawater. Each treatment comparing larvae from CW vs. BFT breeders was then carried out in eight tanks $(n=8)$. All larvae were cultured under identical conditions. The water temperature was maintained at 30-31 ${ }^{\circ} \mathrm{C}$ and a $14 \mathrm{~h}: 10 \mathrm{~h}$ photoperiod was used. The water temperature, survival and growth of the larvae were measured daily.

An algae mixture of Chaetoceros gracilis and Isochrysis galbana was distributed one time at the nii V stage. Thirty hours after stocking, larvae were fed microparticles (INVE Frippack ${ }^{\circledR}$ CD2 30-90 $\mu \mathrm{m}$ ) ad libitum and from day 5 they were fed live preys (Artemia spp.). The amount of food and proportion of Artemia sp. added was adjusted for each larval stage. Prophylactic antibiotic (Oxytetracycline hydrochloride- Limoxin WS- Holland) was applied at a concentration of $15 \mathrm{ppm}$ every three days from the Zoe 2 stage.

Survival and growth were studied at two stages of larval development. For this purpose, 4 tanks per treatment were sacrificed $(n=4)$ when the larvae reached Zoe 2 and Post larvae 1 stages, respectively. To estimate the number of larvae, each tank was drained into a 10 litre bucket over a $250 \mu \mathrm{m}$ filter. Then, after manual mixing, a volumetric count of the larvae was done under a microscope from 10 samples of $25 \mathrm{~mL}$ each. Furthermore, a sample was observed to calculate the proportions of different larval stages.

\subsection{Analysis}

\subsubsection{Zootechnical data}

\subsubsection{Monitoring ovarian maturation and spawning}

After eyestalk ablation and until the end of the experiment (over 10 days), females that were ready to spawn were monitored and systematically inseminated before being placed individually into the spawning tanks. Cumulative relative spawning (CS in \%) can be calculated using the following formula:

$$
\mathrm{CS}=\left(\sum_{i=0}^{n} \mathrm{P} i / \mathrm{Fi}\right)^{*} 100, \text { where } i=\text { day } i ; \mathrm{F} i=\text { number of females on day } i ; \mathrm{P} i=\text { number } \text { of spawns on }
$$
day $i$.

\subsubsection{Determination of spawning rank}


After spawning, the females were individually tagged and returned to their maturation tank. Tagging was carried out by coloured eye rings; the rank of spawns and spawning frequency for each female could thus be determined.

\subsubsection{Number of eggs per spawn}

One hour after spawning, the number of eggs was determined for each spawn. Each spawn was concentrated into 3 litres by draining the spawning tank over a $100 \mu \mathrm{m}$ filter, and then poured in a 10 litre bucket. After manual mixing, a volumetric count of the eggs and nauplii was done from 5 samples of $1 \mathrm{ml}$ each.

\subsubsection{Gonado-somatic index (GSI)}

According to Lagler (1971), the gonado-somatic index (GSI) is the ratio of gonad weight (Wg) to total body weight (Wt). GSI can be calculated using the following formula:

$$
\text { GSI (\%) }=W g / W t \times 100
$$

Average GSI was determined for 3 mature females (ripe ovaries at stage 4; stage determined according to King (1948) and Yano et al. (1988)) per maturation tank for a total of 9 average values (three per tank) per treatment.

\subsubsection{Biochemical analysis}

Only shrimps in inter-molt were sampled for oxidative stress analysis. Molting stages were determined by microscopic examination of antennal scales according to the method of Drach and Tchernigovtzeff (1967). This was to minimize variations, and because changes in physiological parameters are generally observed during the molting cycle in crustaceans.

\subsubsection{Sampling and preservation}

Shrimp and egg sampling - The digestive glands from nine female breeders were sampled for each treatment (three per tank) the day before transferring them to the hatchery. Individual shrimps were caught and directly put in iced sea water $\left(0^{\circ} \mathrm{C}\right)$ to slow down and halt enzyme activity. Individual body weights were recorded. The digestive glands were removed from sampled shrimps, separated into three parts and immediately frozen in liquid nitrogen. The eggs were sampled just one hour after spawning and were processed in the same way.

Biofloc particulate sampling - At the end of the grow-out period, biofloc was filtered through a 100 $\mu \mathrm{m}$ mesh and kept at $-80^{\circ} \mathrm{C}$ until analysed (one sample from each BFT tank). 
Preservation for antioxidant defence analysis - Tissues and biofloc particles were defrosted. One part was homogenized in $4 \mathrm{ml}$ of $10 \mathrm{mM}$ Tris buffer, $1 \mathrm{mM}$ DTPA, $1 \mathrm{mM}$ PMSF, pH 7.4 and the other part in $4 \mathrm{ml}$ of $30 \mathrm{mM}$ trisodium citrate buffer, $0.34 \mathrm{M}$ sodium chloride, $1 \mathrm{mM}$ EDTA specifically for Total Antioxidant Status (TAS) determination. The homogenates were centrifuged at $4000 \mathrm{rpm}$ for $10 \mathrm{~min}$ at $4{ }^{\circ} \mathrm{C}$ and the supernatants were kept at $-80^{\circ} \mathrm{C}$ until analysed. For glutathione (GSH) assays, the supernatants were neutralized with $6 \%$ metaphosphoric acid before storage.

Preservation for lipid analysis - Tissues and particles were dried with a lyophilisator (Alpha 1-2 LD, Christ ${ }^{\circledR}$ ) during 48 hours.

\subsubsection{Antioxidant defences}

All the parameters were determined by biochemical assays with a microplate reader (Bioteck ${ }^{\circledR}$ ).

Determination of antioxidant enzyme activity - Prior to SOD and CAT activity and soluble protein determinations, all samples were heat-shocked to enable cell disruption. This was achieved by submitting the samples three successive times to $1 \mathrm{~min}$ in liquid nitrogen and then defrosting at $37^{\circ} \mathrm{C}$. Total SOD activity was assayed following the method of Marklund and Marklund (1974), which is based on the auto-oxidation of pyrogallol. CAT activity was measured by following the reduction of $\mathrm{H}_{2} \mathrm{O}_{2}$ at $240 \mathrm{~nm}$ according to Clairbone (1985). The soluble protein content was determined by the Bradford method (1976) using bovine serum albumen (Sigma Chemical Company, Inc., USA) as a standard. Enzymatic activities were all expressed as specific activities (IU, nmol.mg of protein ${ }^{-1}$ ).

Glutathione assays and total antioxidant status determination - The amounts of total glutathione (GSH) and oxidized glutathione (GSSG) were determined spectrophotometrically using 5.5-dithio-2nitrobenzoic acid according to the method of Akerboom and Sies (1981). The GSSG/GSH ratio correlating positively with oxidative stress level (Storey, 1996), was calculated. TAS is a quantitative measurement that represents the total contribution from a wide range of antioxidant molecules (Prior and Cao, 1999). Increasing values reflect higher levels of antioxidant defences against free radical reactions. Using TAS to detect the actual antioxidant status in crustaceans has been previously limited to evaluations of the effects of astaxanthin (Pan et al., 2003). TAS was determined using the Randox Kit, referred to as the "Total Antioxidant Status Kit" (Randox Co., Antrim, UK). The TAS of a sample is a quantitative measurement of the state of balance of various antioxidant components under specified reaction conditions. The kit used allows measurement of the total amount of blood antioxidants by inhibition of the transformation of 2.2-azino-di-[3ethylbenzthiazoline sulfonate] $\left(\mathrm{ABTS}^{\oplus}\right)$ into its cation radical $\left(\mathrm{ABTS}^{\oplus}+\right)$ in the presence of a peroxidase (metmyoglobin) and $\mathrm{H}_{2} \mathrm{O}_{2}$. The total protein content was also determined by the Bradford 
method (1976) for GSH and TAS samples. The results were expressed as mmol or $\mu \mathrm{mol}$. $\mathrm{mg}$ protein ${ }^{-1}$, respectively, for GSH and TAS content.

\subsubsection{Lipid analysis}

Lipids were extracted according to Folch et al. (1957) using an accelerated solvent extractor (ASE $350^{\circ}$ ). Neutral lipids (NL) and phospholipids (PL) were separated using Macherey-Nagel Chromafix ${ }^{\circledast}$ Cartridges (ref-731830) with chloroform and methanol. Saponification and methylation were done on the NL and PL fractions. Fatty acid methyl esters were analysed with a gas chromatograph (CLARUS 500-Perkin Elmer ${ }^{\circ}$ ) equipped with a capillary column (BPX70-0.25 $\mu \mathrm{m}-30 \mathrm{Mx0.22MM-SGE}{ }^{\circledR}$ ) and flame ionization detector. The fatty acids (FAs) were identified by comparing their retention times with those of standards.

\subsubsection{Statistical analysis}

Statistical analysis of the data was carried out using XLSTAT software 2012. Percent data (survival rate) were normalized using an arcsine transformation before analysis. The normality of data distribution and homogeneity of variance were tested for biochemical parameters and reproductive performance index data using the Shapiro-Wilk test. Zootechnical data were normally distributed and variances were homogenous; hence, effects of broodstock treatments were tested using a t-test. Biochemical data were not normally distributed and variances were not homogenous; hence, effects of different broodstock treatments and different tissues were tested using the Kruskal-Wallis test.

\section{Results}

\subsection{Grow-out period}

\subsubsection{Water quality parameters}

Descriptive statistics for water quality parameters are given in Table 1. No difference was observed for temperature and dissolved oxygen between the treatments. Furthermore, all the parameters measured were within acceptable ranges for the shrimp Litopenaeus stylirostris (Della Patrona and Brun, 2008). The biofloc productivity in terms of TSS level had a mean value of $97 \mathrm{mg}$ over the course of the experiment. The concentrations of TAN and $\mathrm{NO}_{2}^{-}-\mathrm{N}$ in the BFT and $\mathrm{CW}$ treatments were near zero over the course of trial. In the BFT tanks, Chl a values were relatively high, indicating significant primary production.

\subsubsection{Biofloc glutathione content}


The average GSH content of the biofloc particulates, on a dry matter basis, was $1.22 \pm 0.56 \mathrm{mM} . \mathrm{g}^{-}$ ${ }^{1}$ protein. The sampling was done on the last day when TSS values were $101 \mathrm{mg} \cdot \mathrm{L}^{-1}$. Subsequently, the concentration of GSH in the rearing water was $0.12 \pm 0.06 \mathrm{mM}^{-1} \mathrm{~L}^{-1}$ and its potential dietary availability to the animals was $0.38 \pm 0.19 \mathrm{mM}$ of GSH per gram of shrimp.

\subsubsection{Biofloc lipid composition}

Biofloc particles presented a total lipid concentration of $6.91 \%$ of dry matter. PLS and NLS represented, respectively, $88 \%$ and $12 \%$ of the total lipids which were corresponded to 49.1 and 6.3 mg.g $\mathrm{g}^{-1} \mathrm{DM}$ (Table 2). The main proportion of fatty acids from PLs was represented by saturated fatty acids, n-3 fatty acids, mono-saturated, n-9 fatty acids and n-6 fatty acids with, respectively, 0.59, $0.55,0.32,0.25$ and $0.1 \mathrm{mg} . \mathrm{g}^{-1} \mathrm{DM}$ which represented $29 \%, 32 \%, 18 \%, 15 \%$ and $5 \%$ of total fatty acids. Among saturated fatty acids, myristic acid (C14:0) and palmitic acid (C16:0) presented the highest concentrations. Highly unsaturated fatty acids (HUFA) were dominated by eicosapentaenoic (EPA: C20:5 n-3), arachidonic (ARA: C20:4 n-6) and docosahexaenoic (DHA: C22:6n-3) acids. In contrast, the polyunsaturated fatty acid content (PUFA) linoleic acid (LA): C18:2 n-6 and $\alpha$ linoleic acid (ALA): C18:3 n-3 of the PL fraction from biofloc was low. The NL was dominated by saturated fatty acids (SFA) (C16:0) and EPA (20:5n-3).

\subsubsection{Grow-out zootechnical results}

No difference was found between the two treatments, CW and BFT, in terms of survival rate, growth rate, body weight of females and biomass at the end of the grow-out period (Table 3).

\subsection{Reproduction}

\subsubsection{Survival during the reproduction period}

At the end of the reproduction period in the hatchery, broodstock from BFT exhibited a significantly $(p=0.03)$ higher final survival rate $(79.80 \pm 10.40 \%)$ compared to those from the $\mathrm{CW}$ treatment $(52.60 \pm 8.20 \%)$.

\subsubsection{Spawning rates}

The final cumulative spawning number was significantly higher $(p=0.04)$ in females from BFT (shrimps spawned $52.00 \pm 5.51$ times; $n=75$ females) compare to those from CW (shrimps spawned $35.00 \pm 4.04$ times; $n=75$ females) (Table 4 ). 
The evolution, after eyestalk ablation (EA), of the relative cumulative spawning rate for broodstock from $\mathrm{CW}$ and BFT is shown in Fig $1 \mathrm{~A}$. The spawning rate was similar between the two groups during the first 5 days, whatever the origin of the females. However, from the sixth day after EA, the cumulative spawning rate increased faster for broodstock from the BFT treatment. At the end of the experiment, cumulative spawning rates were $58 \%$ and $88 \%$ for shrimp from the CW and BFT treatments, respectively $(p=0.04)$. Considering the first spawning rank (Fig $1 \mathrm{~B})$, the final spawning rate was significantly lower for CW females (48\%) compared to those from the BFT treatment (70\%) $(p=0.03)$. However, for the second (Fig 1C) spawning rank, the final spawning rate was not significantly different between treatments, at $10 \%$ and $18 \%$ for shrimp from the CW and BFT treatments, respectively $(p>0.05)$.

\subsubsection{Gonado-somatic index (GSI) and number of eggs}

Mature females (stage 4 of vitellogenesis) from CW presented significantly lower GSI ( $p=0.04$ ) compared to those from the BFT treatment with, respectively, $6.56 \% \pm 0.58 \%(n=9)$ and $7.28 \% \pm$ $0.56 \%(n=9)$. This corresponded to a significantly lower $(p=0.04)$ number of eggs laid per spawn by females from CW (175726 $\omega \pm 52976 \omega$ ) compared to females from the BFT treatment (202325 $\omega \pm$ $60118 \omega)$. Finally broodstock from CW produced a lower total cumulative number of eggs $(-72 \%)$ compared to those from the BFT treatment $(p=0.04)$. The total numbers of eggs produced over the trial period based on 75 females from each treatment are presented in Table 4.

\subsection{Antioxidant defences and oxidative stress status of broodstock}

The antioxidant level and oxidative stress status of broodstock at the end of the grow-out period before their transfer to the hatchery are shown in Table 5 . The antioxidant defences in the digestive glands of broodstock from CW compared to those from the BFT treatment exhibited significantly lower levels of GSH $(p=0.02)$ and TAS $(p=0.04)$. No significant difference was revealed regarding measured antioxidant enzyme activities. The GSSG/GSH ratio, a valuable biomarker of oxidative stress (Storey, 1996), was significantly higher $(p=0.04)$ in the digestive glands of broodstock from CW compared to those from the BFT treatment.

\subsection{Lipid composition of the shrimp digestive gland and eggs}

\subsubsection{Digestive gland}

Total lipids were significantly higher in digestive gland from BFT female (229.0 $\left.\pm 41.7 \mathrm{mg} \cdot \mathrm{g}^{-1} \mathrm{DM}\right)$ compared to those from CW female $\left(150.8 \pm 28.4 \mathrm{mg} \cdot \mathrm{g}^{-1} \mathrm{DM} ; p=0.04\right)$. NLs and FA in the NL fraction in the digestive glands of BFT females were, respectively, 2.5 and 3.7 fold higher $(p \leq 0.05)$ compared 
to levels in the digestive glands of females from the CW treatment (Table 6). However, no significant differences were observed for PLs and fatty acids in the PLs fraction. The concentration of each FA was calculated for the NL and PL fractions in the digestive glands (Table 6).

The saturated and mono-saturated acids in the NL fraction were, respectively, 3.1 and 3.8 fold higher in the digestive glands of broodstock from BFT compared to those from the CW treatment $(p \leq 0.05)$. Among the PUFA, ALA and LA in the NLs fraction were, respectively, 3.5 and 3.8 fold higher in females from BFT compared to those from the CW treatment $(p \leq 0.05)$. Among the HUFA, ARA, EPA and DHA acids in the NL fraction were, respectively, 4.9, 4.9 and 7.2 fold higher in females from BFT compared to those from the $\mathrm{CW}$ treatment $(p \leq 0.05)$. However, the treatments, BFT or CW, did not appear to significantly affect the $\sum n-3 / \sum n-6$, PUFA/SFA, DHA/EPA, ARA/EPA, or DPA/ARA ratios. In contrast, no significant differences were observed in the PL content of the digestive gland or in the fatty acids in this lipid fraction according to the origin of the females (BFT or CW).

\subsubsection{Eggs}

Total lipids were significantly higher in eggs from BFT female (266.6 $\left.\pm 8.1 \mathrm{mg} \cdot \mathrm{g}^{-1} \mathrm{DM}\right)$ compared to those from CW female $\left(239.7 \pm 16.8 \mathrm{mg} \cdot \mathrm{g}^{-1} \mathrm{DM} ; p=0.04\right)$. PLs and FA in the PL fraction in eggs from BFT females were, respectively, 2.5 and 2.2 fold higher $(p \leq 0.05)$ compared to their levels in eggs from CW females (Table 7). In eggs from BFT females, PLs represented $40 \%$ of the total lipid content, while those from CW females presented only $18 \%$ ( $p \leq 0.05$ ). The PLs content being 2.5 fold higher in the BFT eggs, the contents of all FA found in this class of lipids were also higher with this treatment compared to CW (Table 7). Thus, in the PLs, the predominant essential fatty acids ARA, EPA and DHA had levels in the eggs that were, respectively, 2.5, 2.8 and 3 fold higher for BFT compared to the CW treatment. Regardless, the treatment (BFT or CW) did not appear to significantly affect the $\sum n-3 / \Sigma n$ 6, PUFA/SFA, DHA/EPA, EPA/ARA, and DPA/ARA ratios, except for the DHA/EPA and ARA/EPA ratios, which were higher in the NL fraction of the BFT treatment, and the PUFA/SFA ratio, which was higher in the PL fraction of the CW treatment. In contrast, no significant differences were observed in the NLs content of the eggs or in the FA in this lipid fraction, regardless of whether the origin of the females was $\mathrm{CW}$ or BFT.

\subsubsection{Digestive glands compared with eggs}

Comparing the ratios of lipids from digestive glands and eggs (Table 6 and 7) in NLs and PLs fractions, PUFA/SFA, $\Sigma n-3 / \sum n-6, D H A / E P A$, and EPA/ARA were significantly lower in digestive glands $(p \leq 0.05)$ which could mean a preferential accumulation of PUFA $n-3$, DHA and EPA in eggs. 


\subsection{Larval survival}

The larval survival rate from BFT females was $37 \%$ and $51 \%$ higher at the Zoe 2 stage $(p=0.02)$ and PL1 stage $(p=0.02)$, respectively (Table 4$)$.

\section{Discussion}

To ensure the reliability of post-larval production in hatcheries, it is important to understand the origins of variations in the reproduction of penaeid shrimps in captivity. The main studies in this area have focused on the influence of nutrition (Wouters et al., 2001), size or age (Peixoto et al., 2004), and season (Crocos and Coman, 1997) on spawning performances and larvae quality. Nevertheless, the consequences of rearing conditions on broodstock shrimp are poorly documented. In our previous study we compared the broodstock from an extensive rearing system (earthen pond) and an intensive system (Biofloc Technology, BFT) (Cardona et al., submitted). The reproductive performances of broodstock from BFT were much higher than those reared extensively in an earthen pond. We hypothesised that the extra energy required for the shrimps from BFT to produce more eggs may come from feeding on biofloc aggregates. To this end, the aim of the present study was to assess the contribution of the biofloc to the lipid nutrition and antioxidant status of the broodstock as reflected in their reproductive performance and the health of larvae of $L$. stylirostris.

\subsection{Health and reproductive performance of the broodstock and larvae}

Broodstock from the BFT treatment showed significantly higher survival rates during the reproduction period in the hatchery. This indicates that the shrimps from BFT, compared to the $\mathrm{CW}$ treatment, were more resistant to the handling stress caused by their fishing, transfer into the hatchery and eyestalk ablation (Wabete et al., 2004). This improved survival of broodstock from BFT has to be linked to their lower GSSG/GSH ratio compared to the shrimps from the CW treatment. Broodstock from BFT exhibited a better antioxidant status too, marked by a higher concentration of GSH and a higher level of TAS. GSH is considered to be one of the most important components of the antioxidant defences of living cells, neutralizing hydroxyl radicals against which there is no enzymatic neutralization (Surai, 2002). The maintenance of appropriate GSH levels is therefore crucial to organisms that periodically undergo oxidative stress (Storey, 1996). GSH can either be endogenously produced or obtained through food. In our previous study and in this study, we showed that biofloc particulates represent a potential source of dietary GSH. Furthermore, TAS, which measures nonenzymatic antioxidant defences, provides integrative information on the susceptibility of an organism to oxidative stress; as its value increases, the level of antioxidant defence against free radical reactions increases (Chien et al., 2003; Lemaire and Chim, 2007). Thus, our result indicates that BFT 
rearing acts in such a way as to increase the antioxidant status of shrimps and to reduce oxidative stress, leading to a better resistance to handling stress undergone during their transfer into the hatchery and the reproduction process (Wabete et al., 2004).

The improved health of shrimp broodstock bred in BFT could contribute to their better reproductive performance. Indeed, females from BFT produced more eggs and spawn more frequently than their counterparts bred in CW. This confirms our previous results obtained by comparing the broodstock reared extensively in earthen ponds with those from BFT (Chim et al., 2010) and the results obtained by Emeranciano et al. (2013) for the shrimp Farfantepenaeus duorarum

The relationship between broodstock and offspring quality is regularly evoked insofar as the vitellus of peneaid shrimp eggs must wholly support the development of the embryo and the first larval stages (nauplius) until moulting occurs into a "first-feeding" larvae (Zoe1) (Harrison, 1990). Indeed, the embryo and pre-feeding larvae of peneaid shrimps are lecitotrophic, as their nutrition is solely supplied by egg yolk reserves (Racotta et al., 2003). The quality and quantity of nutrients in egg yolk is dependent on maternal body reserves, capacity for biosynthesis, and dietary intake during maturation (Harrison, 1990; Racotta et al., 2003). Few studies have shown the relationship between the nutrition of laying shrimps and the quality of their larvae (Cahu et al., 1995; Wyban et al., 1997; Wouters et al., 1999).

\subsection{Dietary lipids from biofloc contribute to broodstock nutrition and egg vitellus.}

These improved qualities of brood stock and larvae can be explained by the contribution of natural food (organic material and microorganisms) from the biofloc system, especially with regard to dietary lipids. Under our culture conditions, we can easily understand that biofloc potentially represents an important food source, especially for PLs and PUFAs. But it is important to note that the proximal composition or nutritional value of biofloc changes according to the culture conditions and is closely related to the microflora of the biofloc environment (Ju et al., 2008; Xu et al., 2012). Thus Crab et al. (2010), unlike in our study, found a lower lipid content (2.3 to 5.4\% of DM) and only a trace of $\mathrm{n}-3$ FA (0.4 to $0.7 \mathrm{mg} \cdot \mathrm{g}^{-1}$ ). Under our culture conditions, the outdoor tanks were exposed to daylight and the biofloc aggregate was a mixture of micro-algae and bacteria. Microalgae biomass is well known to be rich in PUFA and could be an important source of essential FA for aquatic animals (Becker, 1994; Olvera-Novoa et al., 1998).

In our study, the total lipid content of the biofloc was close to $7 \%$ of the dry matter, $88 \%$ of which was represented by PLs. Thus, biofloc is potentially a good source of PLs, which juvenile shrimp 
typically require within the range of 1.2 to $1.5 \%$ (NRC, 2011). FA (n-3) represented the highest proportion of all FAs in the PLs fractions. The essential FAs for shrimps found in biofloc aggregates were dominated by EPA ( $10 \%$ of the dry matter), DHA ( $1.7 \%$ of DM) and ARA ( $1.5 \%$ of DM). The dietary requirements for these 3 essential FAs for $P$. japonicas, $P$. monodon and $L$. vannamei were found to be 0.5 to $1.1 \%$ (EPA and DHA) and 0.5\% (ARA), respectively (NRC, 2011).

The increase of $158 \%$ of NLs in the digestive gland of shrimp reared in BFT compared to shrimps reared in $\mathrm{CW}$ suggests that additional dietary lipid are provided by biofloc. The digestive gland is considered as the main storage organ (Yepiz-Plascencia et al., 2000; Luvizotto-Santos et al., 2003) and the NLs are considered as energy reserves (Vazquez Boucard et al., 2004). Lipids stored in the digestive glands of spawners are necessary for the synthesis of vitellin and the development of oocytes (Vazquez Boucard et al., 2004). Furthermore, the lipid reserves in the digestive glands have been highly correlated with the success of spawning and hatching (Wouters et al., 2001). The nutritional supplementation provided by biofloc also resulted in a significant increase in GSI, which was $11 \%$ higher in BFT compared to the CW treatment. This higher GSI corresponded to an increase of $150 \%$ in the PLs content of the eggs. Thus, it appears that PLs are selectively accumulated in the eggs. In fact, PLs are predominant in shrimp ovaries, mainly phosphatidylcholine and phosphatidylethanolamine (Gehring, 1974; Teshima and Kanazawa, 1983; Mourente and Rodriguez, 1991; Ravid et al., 1999).

Furthermore, we showed in the eggs, mostly in the PLs fraction, an increase of $130 \%$ in the total FA concentration in the BFT relative to the CW treatment. The fatty acids EPA, DHA and ARA contribute the most to this increase in the total FAs. These FAs play a crucial role in the reproduction of peneid shrimps (Alava et al, 1993; Xu et al., 1994; Coman et al., 2011) Xu et al. (1994) postulated that EPA plays a specific role in the ovarian development process, whereas DHA may play some other role in early embryogenesis that is related to the egg hatchability of larval P. chinensis. A similar study was performed by Cahu et al. (1995) with domesticated F. indicus and showed that hatching percentage was related to dietary n-3 HUFA. The ARA content of eggs of $P$. monodon shrimp has also been correlated with fecundity and egg production (Huang et al., 2008; Coman et al., 2011). More broadly, the latter FA is believed to play an important role in reproduction in many cultured marine fish and crustacean species (Stacey and Goetz, 1982; Wouters et al., 2001; Furuita et al., 2003; Mazorra et al., 2003). ARA and EPA are both precursors of prostaglandins and are considered essential for the synthesis of these hormones (Sargent et al., 1999; Bell et al., 1995). Furthermore, in fish, it is believed that EPA competes with the enzyme systems that produce prostaglandins from ARA (Furuita et al., 2003). In our study, the enrichment of eggs with PLs, n-3 HUFA and ARA may also explain the better survival of larvae from females that received the BFT treatment. Indeed, the newly hatched nauplii do not feed and are nourished by the remaining yolk, which must sustain them 
through several moults and through metamorphosis into Zoe 1 larvae within about $48 \mathrm{~h}$ (Harisson, 1990). The quality and quantity of nutrients in egg yolk is dependent on maternal body reserves, their capacity to be biosynthesized, and dietary intake during maturation (Racotta et al., 2003). This is especially the case for essential nutrients such as n-3 HUFA that cannot be synthesized de novo and may be depleted during embryogenesis, the remainder thus being insufficient to support larval development (Kanazawa et al., 1979; Teshima et al., 1989).

Finally, the parallel increase of PUFA, HUFA and also of TAS and GSH, in shrimp tissues from BFT appears consistent. Indeed, the high PUFA and HUFA concentration in lipid fraction of shrimp tissues from BFT make them particularly susceptible to peroxidation (Angel et al., 1999; Peng et al., 2008), and must be protected by appropriate antioxidant defences. The increase of GSH and TAS contents seems associated with that one of PUFA and HUFA; antioxidant protects the animal against oxidative stress (Surai et al., 2001): stress is defined as an imbalance between antioxidant and prooxidants in favour of the last. Thompson et al. (1992) obtained similar results with the rat where lipid peroxidation also increased with decreased liver and kidney GSH levels.

In summary, our results suggest that biofloc lipids are assimilated by brood stock during the grow-out period. These lipids were either set aside in the digestive gland or incorporated directly into the ovary. Once in the hatchery, during the reproduction period, lipid reserves, especially of essential nutrients like n-3 HUFA in the digestive gland, are probably transferred to the ovary in order to complete secondary vitellogenesis. Shrimps reared in BFT obtained complementary dietary lipids by feeding on biofloc aggregates and specifically stored PLs and essential FAs in oocytes that are necessary for embryogenesis and pre-feeding larvae development. In the absence of additional lipids brought by biofloc aggregates, shrimp brood stock, embryos and pre-feeding larvae lacked PLs and essential FAs, which could explain the higher mortality, reduced reproductive performance and larval survival noted for the shrimp brood stock reared in clear water.

\section{Conclusion}

This study shows that BFT improves the antiradical status of the shrimp L. stylirostris, which are thus less susceptible to oxidative stress. Two key pieces of new information emerge from the present study. Firstly, biofloc is a source of further dietary lipids that can act as energetic substrates, but also as a source of PLs and essential fatty acids necessary to sustain reproduction, embryonic and larval development. Second, improving the reproduction of the brood stock also leads to an improvement in the quality of the larvae. This latter result is explained by the improvements in the anti-radical status and nutritional status of brood stock reared in BFT as well as their offspring.

\section{Acknowledgements}


This study was sponsored by the Government and Southern, Northern and Island Provinces of NewCaledonia and the management of marine resources and mining of Tahiti. We would like to thank the Technical Centre for Aquaculture of Tahiti for their help during the running of the experiment, Fabrice Pernet for help with the lipid analyses and Marie Madeleine Le Gall and Karl Renoux for help with biochemical analysis.

\section{References}

Alava, V.R., Kanazawa, A., Teshima, S., S. Koshio., S., 1993. Effect of dietary phospholipids and n-3 highly unsaturated fatty acids on ovarian development of Kuruma prawn. Nippon Suisan Gakkaishi, 59, pp. 345-351

Angel D., Fiedler U., Eden N., Kress N., Adelung D. \& Herut B., 1999. Catalase activity in macro-and microorganisms as an indicator of biotic stress in coastal waters of the eastern Mediterranean Sea. Helgoland Marine Research 53, 209-218.

Aquacop, 1984. Review of ten year of experimental penaeid shrimp culture in Tahiti and New Caledonia (South Pacific). Journal of the World Mariculture Society 15, 73-91.

Avnimelech, Y., 2009. Biofloc Technology - A practical guide Book. Baton Rouge, Louisiana, United States, The World Aquaculture Society.

Akerboom, T.P.M., and Sies, H., 1981. Assay of glutathione, glutathione disulfide and glutathione mixed disulphides in biological samples, Methods Enzymol 77, 373-382.

Becker., E., W., 1994. Applications of algae. Microalgae: Biotechnology and Microbiology, Cambridge University Press, Cambridge, U.K., pp. 250-260

Bell, J. G., Castell, J. D., Tocher, D. R., MacDonald, F. M., \& Sargent, J. R., 1995. Effects of different dietary arachidonic acid: docosahexaenoic acid ratios on phospholipid fatty acid compositions and prostaglandin production in juvenile turbot (Scophthalmus maximus). Fish Physiology and Biochemistry, 14(2), 139-151.

Bendschneider, K., and Robinson, R.J, 1952. A new spectrophotometric method for the determination of nitrite in sea water. J. mar. Res., 11, pp. 87-96.

Bradford, M. M., 1976. A rapid and sensitive method for the quantitation of microgram quantities of protein utilizing the principle of protein-dye binding. Analytical biochemistry, 72(1), 248-254.

Browdy, C.L., Bratford, D., Stokes, A.d., McIntosh, R.P., 2001. Perspectives on the application of closed shrimp culture systems. In: Browdy, C.L., Jory, D.E. (Eds.), The New Wave, Proceedings of the Special Session on Sustainable Shrimp Farming. Worldaqua. Soc., Baton Rouge. LA, pp. 2034.

Burford, M.A., Thompson, P.J., Mclntosh, P.R., Bauman, R.H., Pearson, D.C., 2004. The contribution of flocculated material to shrimp (Litopenaeus vannamei) nutrition in a high-intensity, zero exchange system. Aquaculture 232, 525-537.

Cahu, C., Guillaume, J.C., Stephan, G., Chim, L., 1994. Influence of phospholipid and highly unsaturated fatty acids on spawning rate and egg and tissue composition in Penaeus vannamei fed semi-purified diets. Aquaculture, 126(1), 159-170.

Cahu, C. L., Cuzon, G., \& Quazuguel, P., 1995. Effect of highly unsaturated fatty acids, $\alpha$-tocopherol and ascorbic acid in broodstock diet on egg composition and development of Penaeus indicus. Comparative Biochemistry and Physiology Part A: Physiology, 112(3), 417-424. 
Clairbone, A., 1985. Catalase. In: R. Greenwald, Editor, Handbook of Methods for Oxygen Radical Research, CRC Press, New York , 283-284.

Chien, Y.H., Pan, C.H., Hunter, B., 2003. The resistance to physical stresses by Penaeus monodon juveniles fed diets supplemented with astaxanthin. Aquaculture, 216(1), 177-191.

Chim, L., Huber, M., Lemaire, P., Brun, P., Goguenheim, J., 2010. Floc culture system applied for intensive broodstock farming of the blue shrimp Litopenaeus stylirostris: First trial carried out in New Caledonia. EAS Aquaculture Europe 2010. In book of abstract.

Coman, G. J., Arnold, S. J., Barclay, M., \& Smith, D. M., 2011. Effect of arachidonic acid supplementation on reproductive performance of tank-domesticated Penaeus monodon. Aquaculture Nutrition, 17(2), 141-151.

Crab, R., Chielens, B., Wille, M., Bossier, P., Verstraete, W., 2010. The effect of different carbon sources on the nutritional value of bioflocs, a feed for Macrobrachium rosenbergii postlarvae. Aquaculture Research, 41(4), 559-567.

Crocos, P.J., Coman, G.J., 1997. Seasonal and age variability in the reproductive performance of Penaeus semisulcatus broodstock: optimising broodstock selection. Aquaculture, 155(1), 55-67.

Della Patrona, L., Brun, P., 2008. L'élevage de la crevette bleue en Nouvelle-Calédonie. Litopenaeus stylirostris. Ifremer, Département LEAD (Laboratoire Ecosystème et Aquaculture Durable) en Nouvelle-Calédonie.

Drach, P., Tchernifovtzeff, C., 1967. Sur la méthode de détermination des stades d'intermue et son application générale aux crustacés. Vie Milieu 18, 596-609.

Ekasari, J., Crab, R., Verstraete, W., 2010. Primary nutritional content of bio-flocs cultured with different organic carbon sources and salinity. HAYATI Journal of Biosciences, 17(3), 125.

Emerenciano, M., Cuzon, G., C., Arevalo, M., Gaxiola, G., 2013. Biofloc technology in intensive broodstock farming of the pink shrimp Farfantepenaeus duorarum: spawning performance, biochemical composition and fatty acid profile of eggs. Aquaculture Research.

Epp, M.A., Ziemann, D.A., Schell, D.M., 2002. Carbon and nitrogen dynamics in zero-water exchange shrimp culture as indicated by stable isotope tracers. Aquac. Res. 33, 839-846.

Folch, J., Lees, M., Sloane-Stanley, G.H., 1957. A simple method for the isolation and purification of total lipids from animal tissues. J. biol. Chem, 226(1), 497-509.

Furuita, H., Yamamoto, T., Shima, T., Suzuki, N., \& Takeuchi, T., 2003. Effect of arachidonic acid levels in broodstock diet on larval and egg quality of Japanese flounder Paralichthys olivaceus. Aquaculture, 220(1), 725-735.

Gehring, W. R., 1974. Maturational changes in the ovarian lipid spectrum of the pink shrimp, Penaeus duorarum duorarum Burkenroad. Comparative Biochemistry and Physiology Part A: Physiology, 49(3), 511-524.

Hargreaves J.A., 2006. Photosynthetic suspended-growth systems in aquaculture. Aquacultural Engineering 34, 344-363.

Harrison, K.E., 1990. The role of nutrition in maturation, reproduction and embryonic development of decapod crustaceans: A review. J. Shellfish Res. 9, 1-28.

Holm-Hansen, O. Lorenzen, C.J., Holmes, P.E., Strickland J.D.H., 1965. Fluorometric determination of chlorophyll. Journal du Conseil. Conseil International Pour l'Exploitation de la Mer. 30 (1965). pp. 3-15.

Holmes, R.M., Aminot, A., Kerouel, R., Hooker, B.A., Peterson, B.J., 1999. A simple and precise method for measuring ammonium in marine and freshwater ecosystems. Canadian Journal of Fisheries and Aquatic Sciences 56(10): 1801-1808. 
Huang, J.-H., Jiang, S.-G., Lin, H.-Z., Zhou, F.-L. \& Ye, L., 2008. Effects of dietary highly unsaturated fatty acids and astaxanthin on the fecundity and lipid content of pond-reared Penaeus monodon (Fabricius) broodstock. Aquacult. Res., 39, 240-251.

Ju Z., Forster I., Conquest L., Dominy W. 2008. Enhanced growth effects on shrimp (Litopenaeus vannamei) from inclusion of whole shrimp floc or floc fractions to a formulated diet. Aquaculture Nutrition 14.

Kanazawa, A., Teshima, S. I., \& Ono, K., 1979. Relationship between essential fatty acid requirements of aquatic animals and the capacity for bioconversion of linolenic acid to highly unsaturated fatty acids. Comparative Biochemistry and Physiology Part B: Comparative Biochemistry, 63(3), 295-298.

King, J.E., 1948. A study of the reproductive organs of the common marine shrimp, Penaeus setiferus (Linnaeus). Biol. Bull., 94, pp. 244-262.

Lagler, K.F., 1971. Capture, sampling and examination of fishes. In: Ricker W.E. (ed), Methods for assessment of fish production in freshwaters (2nd ed.). International Biological Programme, 3. Oxford and Edinbourgh : 7-44-44.

Lemaire, P., Chim, L., 2007. Effect of experimental temperature fluctuations on some "oxidative stress» bio-indicators in the digestive gland of the shrimp Litopenaeus stylirostris. In Annual Meeting (pp. 9-13).

Luo, W., Zhao, Y.L., Yao, J.J., 2008. Biochemical composition and digestive enzyme activities during the embryonic development of the redclaw crayfish, Cherax quadricarinatus. Crustaceana, 81(8), 897-915.

Luvizotto-Santos, R., Bianchini, A., 2003. Lipids as energy source during salinity acclimation in the euryhaline crab Chasmagnathus granulata dana, 1851 (crustacea-grapsidae). Journal of Experimental Zoology Part A: Comparative Experimental Biology, 295(2), 200-205.

Marklund, S., and Marklund, G., 1974. Involvement of superoxide anion radical in the auto oxidation of pyrogallol and a convenient assay for superoxide dismutase, European Journal of Biochemistry 47, 469- 474.

Mazorra, C., Bruce, M., Bell, J. G., Davie, A., Alorend, E., Jordan, N., ... \& Bromage, N., 2003. Dietary lipid enhancement of broodstock reproductive performance and egg and larval quality in Atlantic halibut (Hippoglossus hippoglossus). Aquaculture, 227(1), 21-33.

Mourente, G., Rodriguez, A., 1991. Variation in the lipid content of wild-caught females of the marine shrimp Penaeus kerathurus during sexual maturation. Marine Biology, 110(1), 21-28.

NRC (National Research Council)., 2011. Nutrient Requirement of Fish and Shrimp. The National Academy Press, Washington, D.C. US.

Olvera-Novoa, M. A., Domínguez-Cen, L. J., Olivera-Castillo, L., \& Martínez-Palacios, C. A., 1998. Effect of the use of the microalga Spirulina maxima as fish meal replacement in diets for tilapia, Oreochromis mossambicus (Peters), fry. Aquaculture Research, 29(10), 709-715.

Ottogalli, L., Galinie, C., Goxe, D., 1988. Reproduction in captivity of Penaeus stylirostris in New Caledonia J. Aquac. Trop., 3 (1988), pp. 111-125.

Palacios, E., Ibarra, A. M., Ramirez, J. L., Portillo, G., \& Racotta, I. S., 1998. Biochemical composition of eggs and nauplii in white Pacific shrimp, Penaeus vannamei (Boone), in relation to the physiological condition of spawners in a commercial hatchery. Aquaculture Research, 29(3), 183-189. 
Pan, C.H., Chien, Y.H., Hunter, B., 2003. The resistance to ammonia stress of Penaeus monodon Fabricius juvenile fed diets supplemented with astaxanthin. J. Exp. Mar. Biol. Ecol. 297, 107118.

Peixoto, S., Cavalli, R. O., Wasielesky, W., D'Incao, F., Krummenauer, D., Milach, Â. M., 2004. Effects of age and size on reproductive performance of captive Farfantepenaeus paulensis broodstock. Aquaculture, 238(1), 173-182.

Peng S., Chen L., Qin J.G., Hou J., Yu N., Long Z., Ye J. \& Sun X., 2008. Effects of replacement of dietary fish oil by soybean oil on growth performance and liver biochemical composition in juvenile black seabream, Acanthopagrus schlegeli. Aquaculture 276, 154-161.

Prior, R.L., Cao, G., 1999. In vivo total antioxidant capacity: comparison of different analytical methods. Free Radic. Biol. Med. 27, 1173-1181.

Racotta, I.S., Palacios, E., Ibarra, A.M., 2003. Shrimp larval quality in relation to broodstock condition. Aquaculture, 227(1), 107-130.

Ravid, T., Tietz, A., Khayat, M., Boehm, E., Michelis, R., \& Lubzens, E., 1999. Lipid accumulation in the ovaries of a marine shrimp Penaeus semisulcatus (De Haan). Journal of experimental biology, 202(13), 1819-1829.

Sargent, J., McEvoy, L., Estevez, A., Bell, G., Bell, M., Henderson, J., \& Tocher, D., 1999. Lipid nutrition of marine fish during early development: current status and future directions. Aquaculture, 179(1), 217-229.

Schneider O., Sereti V., Eding E.H. \& Verreth J.A.J., 2005. Analysis of nutrient flows in integrated intensive aquaculture systems. Aquacultural Engineering 32, 379-401.

Shyne Anand, P. S., Kohli, M. P. S., Kumar, S., Sundaray, J. K., Roy, S. D., Venkateshwarlu, G., ... \& Pailan, G. H., 2014. Effect of dietary supplementation of biofloc on growth performance and digestive enzyme activities in Penaeus monodon. Aquaculture, 418, 108-115.

Stacey, N. E., \& Goetz, F. W., 1982. Role of prostaglandins in fish reproduction. Canadian Journal of Fisheries and Aquatic Sciences, 39(1), 92-98.

Storey, K.B., 1996. Oxidative stress: animal adaptation in nature. Braz. J. Biol. Res. 29, 1715-1733.

Surai, P. F., Fujihara, N., Speake, B. K., Brillard, J. P., Wishart, G. J., \& Sparks, N. H. C., 2001. Polyunsaturated fatty acids lipid peroxidation and antioxidant protection in avian semem. Asian australien journal of animal sciences, 14(7), 1024-1050.

Surai, P. F., 2002. Natural antioxidants in avian nutrition and reproduction (pp. 5-9). Nottingham: Nottingham University Press.

Tacon, A.G.J., Cody, J., Conquest, L., Divakaran, S., Forster, I.P., Decamp, O., 2002. Effect of culture system on the nutrition and growth performance of Pacific white shrimp Litopenaeus vannamei (Boone) fed different diets. Aquaculture Nutrition 8, 121-137.

Teshima, S. I., \& Kanazawa, A., 1983. Digestibility of dietary lipids in the prawn. Bulletin of the Japanese Society of Scientific Fisheries, 49(6), 963-966.

Teshima, S.I., Kanazawa, A., Koshio, S., Horinouchi, K., 1989. Lipid metabolism of the prawn Penaeus japonicus during maturation: Variation in lipid profiles of the ovary and hepatopancreas. Comparative Biochemistry and Physiology Part B: Comparative Biochemistry, 92(1), 45-49.

Thompson, K. H., Godin, D. V., \& Lee, M., 1992. Tissue antioxidant status in streptozotocin-induced diabetes in rats. Biological trace element research, 35(3), 213-224.

Vazquez Boucard, C. G., Patrois, J., Ceccaldi, H. J., 2004. Exhaustion of lipid reserves in the hepatopancreas of Fenneropenaeus indicusbroodstock in relation to successive spawnings. Aquaculture, 236(1), 523-537. 
Wabete, N., Chim, L., Lemaire, P., Massabuau, J. C., 2004. Caractérisation de problèmes de physiologie respiratoire et d'échanges ioniques associés à la manipulation chez la crevette pénéide Litopenaeus stylirostris à $20 \mathrm{C}$. Styli 2003. Trente ans de crevetticulture en NouvelleCalédonie. In Ifremer. Actes Colloq (Vol. 38, pp. 75-84).

Wabete, N., Chim, L., Pham, D., Lemaire, P., Massabuau, J.C., 2006. A soft technology to improve survival and reproductive performance of Litopenaeus stylirostris by counterbalancing physiological disturbances associated with handling stress. Aquaculture, 260: 181-193.

Wasielesky, W., Atwood, H., Stokes, A. Browdy, C.L., 2006. Effect of natural production in a zero exchange suspended microbial floc based super-intensive culture system for white shrimp Litopenaeus vannamei. Aquaculture 258, 396-403.

Wouters, R., Gomez, L., Lavens, P., \& Calderon, J., 1999. Feeding enriched Artemia biomass to Penaeus vannamei broodstock: Its effect on reproductive performance and larval quality. Journal of Shellfish Research, 18(2), 651-656.

Wouters, R., Lavens, P., Nieto, J., Sorgeloos, P., 2001. Penaeid shrimp broodstock nutrition: an updated review on research and development. Aquaculture, 202(1), 1-21.

Wyban, J., Martinez, G. \& Sweeney, J., 1997. Adding paprika to Penaeus vannamei maturation diet improves nauplii quality. World Aquaculture, 59-62.

Xu, X. L., Ji, W. J., Castell, J. D., O'dor, R. K., 1994. Influence of dietary lipid sources on fecundity, egg hatchability and fatty acid composition of Chinese prawn (Penaeus chinensis) broodstock. Aquaculture, 119(4), 359-370.

Xu, W.J., Pan, L.Q., Sun, X.H., Huang, J., 2012. Effects of bioflocs on water quality, and survival, growth and digestive enzyme activities of Litopenaeus vannamei (Boone) in zero-water exchange culture tanks. Aquaculture Research, http://dx.doi.org/10.1111/j.13652109.2012.03115.x.

Xu, W.J., Pan, L.Q., 2013. Enhancement of immune response and antioxidant status of Litopenaeus vannamei juvenile in biofloc-based culture tanks manipulating high $\mathrm{C} / \mathrm{N}$ ratio of feed input. Aquaculture, 412, 117-124.

Yano, I., Tsukimura, B.T., Sweeney, J.N., Wyban, J.A., 1988. Induced ovarian maturation of Penaeus vannamei by implantation of lobster ganglion. J. World Aquacult. Soc., 19 (4), pp. 204-209.

Yepiz-Plascencia, G., Galván, T. G., Vargas-Albores, F., \& García-Bañuelos, M., 2000. Synthesis of hemolymph high-density lipoprotein $\beta$-glucan binding protein by Penaeus vannamei shrimp hepatopancreas. Marine Biotechnology, 2(5), 485-492. 


\section{Captions of tables and figures}

Table 1: The overall means \pm s.d of measured water quality parameters for both grow-out systems.

Table 2: Fatty acid concentrations in the neutral and phospholipid fractions in biofloc particles.

Values are means \pm s.d $(n=3)$. All concentrations are reported as $\mathrm{mg} . \mathrm{g}^{-1}$ dry matter. "n.d" indicates not determined. (PUFA: Poly-unsaturated fatty acids; SFA: saturated fatty acids; LA: Linoleic acid; ALA: $\alpha$-linoleic acid; ETA: Eicosatetraenoic acid; ARA Arachidonic acid; EPA : eicopentaeonic acid; DPA, docosapentaeonic acid; DHA : Docosahexaenoic acid)

Table 3: Zootechnical performances of the two rearing systems (CW vs. BFT) at the end of the grow-out period.

Values are means \pm s.d $(n=3)$. The stars indicate "significant" differences between treatments (*p $\leq 0.05 ;$ "n.s" not significant).

Table 4: Total spawning number, total eggs produced based on 75 females per treatment (CW vs. BFT) and larval survival rates at the Zoe 2 and PL1 stages.

Values are tank means \pm s.d. The stars indicate "significant" differences between treatments (*p $\leq 0.05 ;$ "n.s" not significant).

Table 5: Oxidative status and antioxidant defences in the digestive glands of females from both treatments (CW and BFT).

Values are means \pm s.d $(n=9)$. The stars indicate "significant" differences between treatments (*p $\leq 0.05 ;$ "n.s" not significant).

Table 6: Fatty acid concentrations in the neutral and phospholipid fractions in digestive glands from CW or BFT females.

Values are means \pm s.d $(n=9)$. All concentrations are reported as mg.g ${ }^{-1}$ dry matter. "n.d" indicates not determined. The stars indicate "significant" differences between treatments $\left({ }^{*} p \leq\right.$ 0.05 ; "n.s" not significant). 
Table 7: Fatty acid concentrations in the neutral and phospholipid fractions in eggs from CW or BFT females.

Values are means \pm s.d $(n=9)$. All concentrations are reported as mg.g ${ }^{-1}$ dry matter. "n.d" indicates not determined. The stars indicate "significant" differences between treatments $(* p \leq$ 0.05 ; "n.s" not significant).

Figure 1: Evolution of cumulative spawning rates after eyestalk ablation $\left(^{*}\right)$ for 75 females per treatment (CW and BFT), including all spawns (A) and according to spawning rank 1 (B) or spawning rank $2(\mathrm{C})$. 
Figure 1
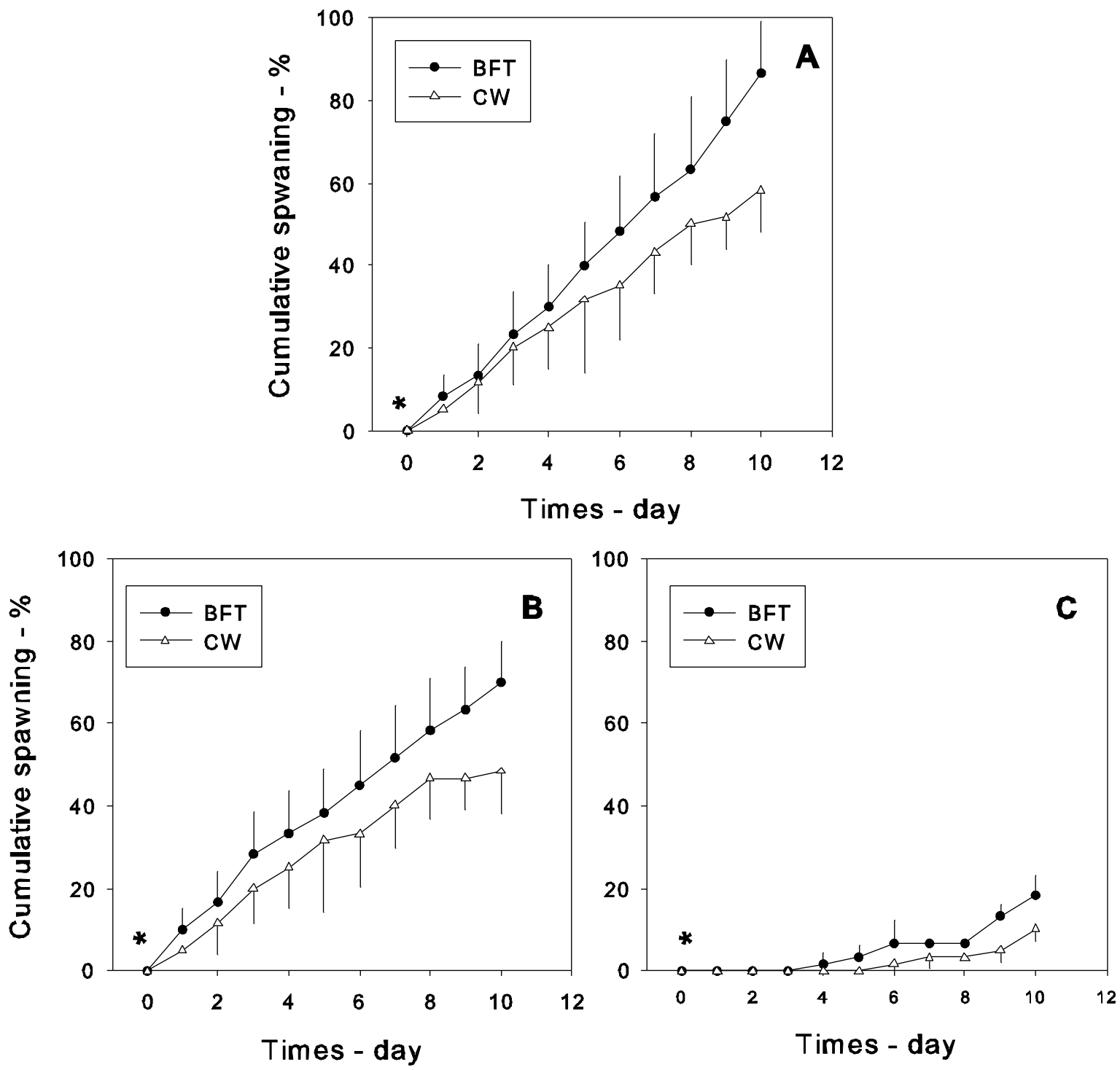
Table 1

\begin{tabular}{lll}
\hline Parameters & $\mathrm{CW}$ & $\mathrm{BFT}$ \\
\hline Temperature $\left({ }^{\circ} \mathrm{C}\right)$ & $25.54 \pm 0.78$ & $24.70 \pm 1.30$ \\
Dissolved Oxygen $\left(\mathrm{mg} . \mathrm{L}^{-1}\right)$ & $7.09 \pm 0.76$ & $6.80 \pm 0.64$ \\
$\mathrm{pH}$ & $8.20 \pm 0.06$ & $7.78 \pm 0.09$ \\
Chlorophyll a $\left(\mu \mathrm{g} . \mathrm{L}^{-1}\right)$ & $0.39 \pm 0.48$ & $77.91 \pm 38.12$ \\
$\mathrm{TSS}\left(\mathrm{mg} . \mathrm{L}^{-1}\right)$ & $3.20 \pm 2.30$ & $97.10 \pm 18.20$ \\
$\mathrm{TAN}\left(\mathrm{mg} . \mathrm{L}^{-1}\right)$ & $0.00 \pm 0.00$ & $0.00 \pm 0.00$ \\
$\mathrm{NO}_{2}{ }^{-}\left(\mathrm{mg} . \mathrm{L}^{-1}\right)$ & $0.00 \pm 0.00$ & $0.01 \pm 0.01$ \\
\hline
\end{tabular}


Table 2

\begin{tabular}{|c|c|c|}
\hline Fraction & $\begin{array}{l}\text { Neutral } \\
\text { lipids }\end{array}$ & Phospholips \\
\hline \multicolumn{3}{|c|}{ Concentration (mg.g $\left.{ }^{-1} \mathrm{DM}\right)$} \\
\hline Total lipids & \multicolumn{2}{|c|}{$69.1 . \pm 8.80$} \\
\hline Total fraction & $6.30 \pm 1.00$ & $49.1 \pm 4.20$ \\
\hline$\sum \mathrm{FA}$ & $1.98 \pm 0.40$ & $19.41 \pm 1.25$ \\
\hline $14: 0 \mathrm{~s}$ & $0.08 \pm 0.01$ & $2.12 \pm 0.43$ \\
\hline 14:1n-9 & $0.01 \pm 0.00$ & $0.25 \pm 0.05$ \\
\hline $16: 0 \mathrm{~s}$ & $0.36 \pm 0.15$ & $2.66 \pm 0.29$ \\
\hline $16: 1 n-9$ & $0.14 \pm 0.01$ & $2.21 \pm 0.34$ \\
\hline $18: 0 \mathrm{~s}$ & $0.13 \pm 0.06$ & $0.33 \pm 0.05$ \\
\hline $18: 1 n-11$ & $0.01 \pm 0.00$ & $0.02 \pm 0.01$ \\
\hline $18: 1 n-7$ & $0.05 \pm 0.02$ & $0.62 \pm 0.36$ \\
\hline 18:1n-9 & $0.09 \pm 0.05$ & $0.36 \pm 0.06$ \\
\hline $18: 1 n-9 t$ & $0.00 \pm 0.00$ & $0.01 \pm 0.00$ \\
\hline $18: 2 n-6(L A)$ & $0.04 \pm 0.01$ & $0.23 \pm 0.03$ \\
\hline $18: 3 n-3$ (ALA) & $0.01 \pm 0.00$ & $0.07 \pm 0.01$ \\
\hline $18: 3 n-6$ & n.d & n.d \\
\hline $18: 4 n-3$ & $0.02 \pm 0.00$ & $0.56 \pm 0.10$ \\
\hline $20: 0 \mathrm{~s}$ & $0.01 \pm 0.00$ & $0.04 \pm 0.01$ \\
\hline $20: 1 n-11$ & n.d & n.d \\
\hline $20: 1 n-7$ & $0.01 \pm 0.00$ & $0.04 \pm 0.00$ \\
\hline 20:1n-9 & $0.01 \pm 0.00$ & $0.04 \pm 0.00$ \\
\hline $20: 2 n-6$ & n.d & n.d \\
\hline $20: 3 n-3$ & n.d & n.d \\
\hline $20: 3 n-6$ & $0.00 \pm 0.00$ & $0.03 \pm 0.00$ \\
\hline $20: 4 n-3$ (ETA) & $0.01 \pm 0.00$ & $0.07 \pm 0.01$ \\
\hline $20: 4 n-6$ (ARA) & $0.06 \pm 0.01$ & $0.65 \pm 0.05$ \\
\hline 20:5n-3 (EPA) & $0.42 \pm 0.08$ & $4.41 \pm 0.22$ \\
\hline $22: 0 \mathrm{~s}$ & $0.00 \pm 0.00$ & $0.02 \pm 0.01$ \\
\hline $22: 1 n-11$ & n.d & n.d \\
\hline $22: 1 n-9$ & n.d & n.d \\
\hline $22: 5 n-3(\mathrm{DPA})$ & $0.01 \pm 0.00$ & $0.11 \pm 0.04$ \\
\hline 22:6n-3 (DHA) & $0.09 \pm 0.04$ & $0.70 \pm 0.08$ \\
\hline $24: 0 \mathrm{~s}$ & $0.02 \pm 0.01$ & $0.26 \pm 0.03$ \\
\hline $24: 1 n-9$ & n.d & $0.01 \pm 0.01$ \\
\hline
\end{tabular}

Categories (mg.g $\left.{ }^{-1} \mathrm{DM}\right)$

$\begin{array}{lll}\sum \text { Saturated } & 0.59 \pm 0.23 & 5.44 \pm 0.71 \\ \sum \text { Mono satured } & 0.32 \pm 0.08 & 3.54 \pm 0.59 \\ \sum \text { PUFA } & 0.63 \pm 0.05 & 6.81 \pm 0.37 \\ \sum \mathrm{n}-3 & 0.55 \pm 0.06 & 5.90 \pm 0.41 \\ \sum \mathrm{n}-6 & 0.10 \pm 0.01 & 0.91 \pm 0.05 \\ \sum \mathrm{n}-9 & 0.26 \pm 0.05 & 2.87 \pm 0.43\end{array}$




\begin{tabular}{lll}
\hline Ratio & & \\
$\sum \mathrm{n}-3 / \sum \mathrm{n}-6$ & $5.33 \pm 1.06$ & $6.53 \pm 0.78$ \\
PUFA/SFA & $1.29 \pm 0.71$ & $1.26 \pm 0.17$ \\
DHA/EPA & $0.21 \pm 012$ & $0.16 \pm 0.02$ \\
ARA/EPA & $0.15 \pm 0.02$ & $0.15 \pm 0.18$ \\
DPA/ARA & $0.17 \pm 0.05$ & $0.17 \pm 0.36$ \\
\hline
\end{tabular}


Table 3

\begin{tabular}{llll}
\hline \multicolumn{1}{c}{ Parameters } & \multicolumn{1}{c}{ CW } & \multicolumn{1}{c}{ BFT } & S \\
\hline Survival rate $(\%)$ & $49.12 \pm 13.98$ & $53.72 \pm 7.29$ & n.s \\
Growth rate $\left(\right.$ g.day $\left.^{-1}\right)$ & $0.15 \pm 0.01$ & $0.16 \pm 0.01$ & n.s \\
Females final weight $(\mathrm{g})$ & $48.25 \pm 0.84$ & $48.93 \pm 0.70$ & n.s \\
Finale biomass $\left(\mathrm{g} . \mathrm{m}^{-2}\right)$ & $284.41 \pm 26.98$ & $315.42 \pm 14.26$ & n.s \\
\hline
\end{tabular}


Table 4

\begin{tabular}{llll}
\hline Parameters & CW & BFT & S \\
\hline Total spawning number & $35.00 \pm 4.04$ & $52.00 \pm 5.51$ & $*$ \\
Total eggs number $\times 10^{7}$ & $0.61 \pm 0.07$ & $1.05 \pm 0.11$ & $*$ \\
& $70.06 \pm$ & & \\
Larval survival zoe 2 & 13.79 & $95.90 \pm 7.29$ & $*$ \\
Larval survival Post larvae 1 & $45.48 \pm 7.67$ & $68.73 \pm$ & $*$ \\
stage & & 12.60 & \\
\hline
\end{tabular}


Table 5

\begin{tabular}{|c|c|c|c|}
\hline Parameters & CW & $\mathrm{BFT}$ & $S$ \\
\hline TAS $\left(\mu\right.$ mol.mg protein $\left.{ }^{-1}\right)$ & $\begin{array}{l}53.66 \pm \\
10.48\end{array}$ & $\begin{array}{l}65.61 \pm \\
6.54\end{array}$ & $*$ \\
\hline SOD (U.mg protein $\left.{ }^{-1}\right)$ & $3.31 \pm 0.56$ & $6.36 \pm 4.39$ & n.s \\
\hline $\begin{array}{l}\text { Catalase }(\mu \text { mol.min } \\
\left.\text { protein }^{-1}\right)\end{array}$ & $0.61 \pm 0.51$ & $1.24 \pm 0.45$ & n.s \\
\hline GSH (mmol.mg protein $\left.{ }^{-1}\right)$ & $1.20 \pm 0.49$ & $2.56 \pm 1.04$ & $*$ \\
\hline GSSH/GSH & $0.40 \pm 0.10$ & $0.15 \pm 0.03$ & $*$ \\
\hline
\end{tabular}




\begin{tabular}{|c|c|c|c|c|c|c|}
\hline \multirow{2}{*}{$\begin{array}{l}\text { Fraction } \\
\text { Treatments }\end{array}$} & \multicolumn{2}{|c|}{ Neutral lipids } & \multicolumn{4}{|c|}{ Phospholips } \\
\hline & CW & BFT & $\mathbf{S}$ & CW & BFT & $\mathbf{S}$ \\
\hline \multicolumn{7}{|c|}{ concentration (mg.g-1 DM) } \\
\hline Total & $\begin{array}{l}30.30 \pm \\
13.40 \\
13.78 \pm\end{array}$ & $\begin{array}{l}77.50 \pm \\
17.20 \\
50.96 \pm \\
17.18\end{array}$ & $*$ & $\begin{array}{l}106.70 \pm \\
18.50 \\
57.17 \pm\end{array}$ & $\begin{array}{l}108.10 \pm \\
17.50 \\
71.32 \pm\end{array}$ & n.s \\
\hline$\sum \mathrm{FA}$ & 11.50 & 17.18 & & 16.84 & 23.31 & n.s \\
\hline $14: 0 \mathrm{~s}$ & $0.21 \pm 0.17$ & $0.35 \pm 0.19$ & & $0.92 \pm 0.47$ & $0.89 \pm 0.39$ & n.s \\
\hline 14:1n-9 & $0.03 \pm 0.02$ & $0.04 \pm 0.02$ & n. & $0.10 \pm 0.09$ & $0.08 \pm 0.09$ & n.s \\
\hline $16: 0 \mathrm{~s}$ & $2.79 \pm 2.30$ & $8.70 \pm 3.00$ & $*$ & $11.69 \pm 4.46$ & $16.47 \pm 1.49$ & n.s \\
\hline $16: 1 n-9$ & $0.36 \pm 0.31$ & $0.77 \pm 0.28$ & $*$ & $1.44 \pm 0.72$ & $1.47 \pm 0.60$ & n.s \\
\hline $18: 0 \mathrm{~s}$ & $0.69 \pm 0.51$ & $2.09 \pm 0.30$ & $*$ & $0.39 \pm 0.85$ & $3.60 \pm 0.21$ & n.s \\
\hline $18: 1 n-11$ & $0.04 \pm 0.04$ & $0.12 \pm 0.03$ & $*$ & $0.18 \pm 0.09$ & $0.16 \pm 0.02$ & n.s \\
\hline $18: 1 n-7$ & $0.54 \pm 0.46$ & $1.78 \pm 0.55$ & $*$ & $2.12 \pm 0.81$ & $2.40 \pm 0.69$ & n.s \\
\hline 18:1n-9 & $4.24 \pm 3.61$ & $16.79 \pm 5.77$ & $*$ & $14.63 \pm 6.60$ & $20.01 \pm 6.75$ & n.s \\
\hline $18: 1 n-9 t$ & n.d & n.d & - & n.d & n.d & - \\
\hline $18: 2 n-6$ (LA) & $1.67 \pm 1.58$ & $6.32 \pm 2.73$ & $*$ & $6.96 \pm 1.84$ & $8.81 \pm 3.71$ & n.s \\
\hline $18: 3 n-3$ (ALA) & $0.12 \pm 0.13$ & $0.42 \pm 0.24$ & $*$ & $0.61 \pm 0.19$ & $0.84 \pm 0.43$ & n.s \\
\hline $18: 3 n-6$ & & n.d & - & n.d & n.d & - \\
\hline $18: 4 n-3$ & & n.d & - & n.d & n.d & - \\
\hline $20: 0 \mathrm{~s}$ & $0.06 \pm 0.04$ & $0.24 \pm 0.08$ & $*$ & $0.19 \pm 0.12$ & $0.21 \pm 0.05$ & n.s \\
\hline $20: 1 n-11$ & $0.09 \pm 0.08$ & $0.42 \pm 0.21$ & $*$ & $0.26 \pm 0.15$ & $0.37 \pm 0.16$ & n.s \\
\hline $20: 1 n-7$ & $0.06 \pm 0.05$ & $0.24 \pm 0.10$ & $*$ & $0.16 \pm 0.12$ & $0.21 \pm 0.09$ & n.s \\
\hline 20:1n-9 & $9 \pm 0.59$ & $2.95 \pm 1.28$ & $*$ & $1.95 \pm 1.10$ & $2.44 \pm 0.74$ & n.s \\
\hline $20: 2 n-6$ & $0.09 \pm 0.08$ & $0.56 \pm 0.28$ & $*$ & $0.34 \pm 0.06$ & $0.54 \pm 0.22$ & n.s \\
\hline $20: 3 n-3$ & $0.02 \pm 0.02$ & $0.13 \pm 0.07$ & $*$ & $0.09 \pm 0.02$ & $0.16 \pm 0.10$ & n.s \\
\hline $20: 3 n-6$ & $0.02 \pm 0.02$ & $0.06 \pm 0.05$ & $*$ & $0.01 \pm 0.02$ & $0.05 \pm 0.05$ & n.s \\
\hline $20: 4 n-3($ ETA) & $0.03 \pm 0.03$ & $0.20 \pm 0.11$ & $*$ & $0.17 \pm 0.04$ & $0.28 \pm 0.16$ & n.s \\
\hline 20:4n-6 (ARA) & $0.09 \pm 0.07$ & $0.44 \pm 0.13$ & $*$ & $0.96 \pm 0.43$ & $0.84 \pm 0.18$ & n.s \\
\hline 20:5n-3 (EPA) & $0.23 \pm 0.19$ & $1.15 \pm 0.26$ & $*$ & $3.07 \pm 1.43$ & $3.42 \pm 0.87$ & n.s \\
\hline $22: 0 \mathrm{~s}$ & $0.07 \pm 0.06$ & $0.33 \pm 0.12$ & $*$ & $0.21 \pm 0.18$ & $0.24 \pm 0.05$ & n.s \\
\hline $22: 1 n-11$ & $0.23 \pm 0.19$ & $1.00 \pm 0.55$ & $*$ & $0.52 \pm 0.42$ & $0.60 \pm 0.18$ & n.s \\
\hline $22: 1 n-9$ & $0.11 \pm 0.09$ & $0.47 \pm 0.23$ & $*$ & $0.28 \pm 0.20$ & $0.31 \pm 0.09$ & n.s \\
\hline 22:5n-3 (DPA) & $0.05 \pm 0.05$ & $0.29 \pm 0.18$ & $*$ & $0.25 \pm 0.06$ & $0.33 \pm 0.19$ & n.s \\
\hline 22:6n-3 (DHA) & $0.39 \pm 0.37$ & $2.78 \pm 1.63$ & $*$ & $2.15 \pm 0.57$ & $2.95 \pm 1.32$ & n.s \\
\hline $24: 0 \mathrm{~s}$ & $0.02 \pm 0.02$ & $0.11 \pm 0.07$ & $*$ & $0.05 \pm 0.01$ & $0.08 \pm 0.04$ & n.s \\
\hline 24:1n-9 & $0.05 \pm 0.04$ & $0.20 \pm 0.07$ & $*$ & $0.12 \pm 0.10$ & $0.12 \pm 0.03$ & n.s \\
\hline \multicolumn{7}{|c|}{ Categories $\left(\mathrm{mg.g}^{-1} \mathrm{DM}\right)$} \\
\hline$\sum$ Saturated & $3.83 \pm 0.31$ & $11.82 \pm 3.47$ & $*$ & $16.91 \pm 6.04$ & $21.49 \pm 7.32$ & n.s \\
\hline$\sum$ Mono saturated & $6.44 \pm 5.45$ & $24.76 \pm 8.84$ & $*$ & $21.64 \pm 6.34$ & $28.05 \pm 9.39$ & n.s \\
\hline$\sum$ PUFA & $2.70 \pm 2.53$ & $12.32 \pm 5.42$ & $*$ & $14.62 \pm 1.11$ & $18.22 \pm 6.47$ & n.s \\
\hline$\sum \mathrm{n}-3$ & $0.84 \pm 0.80$ & $4.95 \pm 2.39$ & $*$ & $6.34 \pm 1.88$ & $7.98 \pm 2.65$ & n.s \\
\hline$\sum \mathrm{n}-6$ & $1.86 \pm 1.74$ & $7.37 \pm 3.05$ & $*$ & $8.27 \pm 1.50$ & $10.24 \pm 0.40$ & n.s \\
\hline
\end{tabular}




\begin{tabular}{lllllll}
$\sum \mathrm{n}-9$ & $7.46 \pm 5.48$ & $21.21 \pm 7.46$ & $*$ & $18.51 \pm 8.79$ & $24.44 \pm 8.27$ & n.s \\
\hline Ratio & & & & & & \\
$\sum \mathrm{n}-3 / \sum \mathrm{n}-6$ & $0.69 \pm 0.46$ & $0.65 \pm 0.08$ & n.s & $0.81 \pm 0.39$ & $0.79 \pm 0.12$ & n.s \\
PUFA/SFA & $0.62 \pm 0.18$ & $1.03 \pm 0.39$ & n.s & $0.96 \pm 0.39$ & $0.85 \pm 0.15$ & n.s \\
DHA/EPA & $1.34 \pm 0.71$ & $2.28 \pm 1.06$ & n.s & $0.74 \pm 0.15$ & $0.86 \pm 0.34$ & n.s \\
ARA/EPA & $0.38 \pm 0.03$ & $0.38 \pm 0.07$ & n.s & $0.28 \pm 0.30$ & $0.21 \pm 0.25$ & n.s \\
DPA/ARA & $0.43 \pm 0.20$ & $0.63 \pm 0.29$ & n.s & $0.29 \pm 0.28$ & $0.36 \pm 0.41$ & n.s \\
\hline
\end{tabular}


Table 7

\begin{tabular}{|c|c|c|c|c|c|c|}
\hline \multirow{2}{*}{$\begin{array}{l}\text { Fraction } \\
\text { Treatments }\end{array}$} & \multicolumn{3}{|c|}{ Neutral lipids } & \multicolumn{3}{|c|}{ Phospholips } \\
\hline & CW & BFT & $\mathbf{S}$ & CW & BFT & $\mathbf{S}$ \\
\hline \multicolumn{7}{|c|}{ Concentration $\left(\mathrm{mg} \mathrm{g}^{-1} \mathrm{DM}\right)$} \\
\hline Total & $\begin{array}{l}73.90 \pm \\
61.70 \\
59.51 \pm\end{array}$ & $\begin{array}{l}80.20 \pm \\
6.00 \\
61.13 \pm\end{array}$ & n.s & $\begin{array}{l}43.00 \pm \\
32.30\end{array}$ & $\begin{array}{l}107.60 \pm \\
32.80\end{array}$ & $*$ \\
\hline$\sum \mathrm{FA}$ & 49.92 & 9.81 & n.s & $28.59 \pm 3.26$ & $65.77 \pm 24.32$ & $*$ \\
\hline $14: 0 \mathrm{~s}$ & $1.75 \pm 1.53$ & $1.17 \pm 0.36$ & n.s & $0.29 \pm 0.22$ & $1.77 \pm 0.63$ & $*$ \\
\hline $14: 1 n-9$ & $\begin{array}{l}0.08 \pm 0.07 \\
15.14 \pm\end{array}$ & $\begin{array}{l}\text { n.d } \\
14.13 \pm\end{array}$ & & n.d & n.d & - \\
\hline $16: 0 \mathrm{~s}$ & 12.86 & 2.75 & n.s & $4.03 \pm 3.24$ & $15.77 \pm 6.46$ & $*$ \\
\hline $16: 1 n-9$ & $3.42 \pm 2.91$ & $3.00 \pm 0.77$ & n.s & $0.74 \pm 0.58$ & $3.71 \pm 1.53$ & $*$ \\
\hline $18: 0 \mathrm{~s}$ & $2.07 \pm 1.72$ & $2.59 \pm 0.42$ & n.s & $1.62 \pm 1.32$ & $3.46 \pm 0.83$ & $*$ \\
\hline $18: 1 n-11$ & $0.11 \pm 0.09$ & $0.13 \pm 0.02$ & n.s & $0.05 \pm 0.04$ & $0.14 \pm 0.05$ & $*$ \\
\hline $18: 1 n-7$ & $9.11 \pm 7.62$ & $\begin{array}{l}2.37 \pm 1.43 \\
10.72 \pm\end{array}$ & n.s & $0.40 \pm 0.51$ & $2.08 \pm 0.82$ & $*$ \\
\hline $18: 1 n-9$ & $9.11 \pm 7.62$ & 1.43 & n.s & $2.18 \pm 1.76$ & $8.07 \pm 3.20$ & $*$ \\
\hline $18: 1 n-9 t$ & n.d & n.d & - & n.d & n.d & - \\
\hline $18: 2 n-6$ (LA) & $2.05 \pm 1.72$ & $1.88 \pm 0.33$ & n.s & $0.57 \pm 0.46$ & $1.92 \pm 0.77$ & $*$ \\
\hline $18: 3 n-3$ (ALA) & $0.35 \pm 0.30$ & $0.25 \pm 0.07$ & n.s & $0.11 \pm 0.09$ & $0.44 \pm 0.18$ & $*$ \\
\hline $18: 3 n-6$ & $0.01 \pm 0.01$ & $0.03 \pm 0.02$ & n.s & $0.00 \pm 0.00$ & $0.02 \pm 0.03$ & $*$ \\
\hline $18: 4 n-3$ & $0.31 \pm 0.26$ & $0.28 \pm 0.07$ & n.s & $0.04 \pm 0.02$ & $0.28 \pm 0.13$ & $*$ \\
\hline $20: 0 \mathrm{~s}$ & $0.25 \pm 0.21$ & $0.33 \pm 0.05$ & n.s & $0.07 \pm 0.05$ & $0.19 \pm 0.08$ & $*$ \\
\hline $20: 1 n-11$ & & n.d & - & n.d & n.d & - \\
\hline $20: 1 n-7$ & $0.23 \pm 0.19$ & $0.32 \pm 0.04$ & n.s & $0.05 \pm 0.04$ & $0.17 \pm 0.06$ & $*$ \\
\hline 20:1n-9 & $0.85 \pm 0.70$ & $1.23 \pm 0.16$ & n.s & $0.25 \pm 0.20$ & $0.76 \pm 0.21$ & $*$ \\
\hline $20: 2 n-6$ & $0.22 \pm 0.18$ & $0.29 \pm 0.04$ & n.s & $0.09 \pm 0.07$ & $0.26 \pm 0.06$ & $*$ \\
\hline $20: 3 n-3$ & $0.13 \pm 0.11$ & $0.15 \pm 0.03$ & n.s & $0.04 \pm 0.03$ & $0.16 \pm 0.07$ & $*$ \\
\hline $20: 3 n-6$ & $0.06 \pm 0.05$ & $0.07 \pm 0.01$ & n.s & $0.00 \pm 0.00$ & $0.07 \pm 0.02$ & $*$ \\
\hline $20: 4 n-3$ (ETA) & $0.15 \pm 0.13$ & $0.14 \pm 0.04$ & n.s & $0.04 \pm 0.03$ & $0.18 \pm 0.08$ & $*$ \\
\hline $20: 4 n-6$ (ARA) & $0.72 \pm 0.60$ & $0.72 \pm 0.16$ & n.s & $0.53 \pm 0.43$ & $1.31 \pm 0.26$ & $*$ \\
\hline 20:5n-3 (EPA) & $5.68 \pm 4.80$ & $3.75 \pm 1.06$ & n.s & $3.48 \pm 2.86$ & $9.77 \pm 3.10$ & $*$ \\
\hline $22: 0 \mathrm{~s}$ & $0.01 \pm 0.02$ & $0.04 \pm 0.01$ & n.s & $0.02 \pm 0.02$ & $0.03 \pm 0.03$ & $*$ \\
\hline $22: 1 n-11$ & n.d & $0.23 \pm 0.40$ & - & n.d & n.d & - \\
\hline $22: 1 n-9$ & $0.06 \pm 0.05$ & $0.08 \pm 0.01$ & n.s & n.d & $0.03 \pm 0.00$ & - \\
\hline $22: 5 n-3$ (DPA) & $0.39 \pm 0.32$ & $\begin{array}{l}0.37 \pm 0.09 \\
12.97 \pm\end{array}$ & n.s & $0.14 \pm 0.11$ & $0.49 \pm 0.17$ & $*$ \\
\hline 22:6n-3 (DHA) & $10.68 \pm 8.86$ & 1.21 & n.s & $3.45 \pm 2.78$ & $10.49 \pm 4.11$ & $*$ \\
\hline $24: 0 \mathrm{~s}$ & $0.14 \pm 0.12$ & $0.19 \pm 0.02$ & n.s & $0.05 \pm 0.04$ & $0.12 \pm 0.03$ & $*$ \\
\hline 24:1n-9 & n.d & n.d & - & n.d & n.d & - \\
\hline \multicolumn{7}{|c|}{ Categories (mg.g $\left.{ }^{-1} \mathrm{DM}\right)$} \\
\hline$\sum$ Saturated & $\begin{array}{l}19.66 \pm \\
16.41 \\
15.83 \pm\end{array}$ & $\begin{array}{l}18.44 \pm \\
3.59 \\
17.87 \pm\end{array}$ & n.s & $6.07 \pm 4.88$ & $21.33 \pm 8.00$ & $*$ \\
\hline$\sum$ Mono saturated & 13.25 & 0.26 & n.s & $3.91 \pm 3.13$ & $14.96 \pm 5.84$ & $*$ \\
\hline
\end{tabular}




\begin{tabular}{lllllll} 
& $20.75 \pm$ & $20.92 \pm$ & & & & \\
$\sum$ PUFA & 17.31 & 3.01 & n.s & $8.48 \pm 6.7$ & $25.37 \pm 8.93$ & $*$ \\
& $17.69 \pm$ & $17.92 \pm$ & & & & \\
$\sum \mathrm{n}-3$ & 14.77 & 2.47 & n.s & $7.29 \pm 5.91$ & $21.80 \pm 7.83$ & $*$ \\
$\sum \mathrm{n}-6$ & $3.05 \pm 2.55$ & $3.00 \pm 0.53$ & n.s & $1.19 \pm 0.96$ & $3.57 \pm 1.10$ & $*$ \\
& $13.51 \pm$ & $15.03 \pm$ & & & & \\
$\sum \mathrm{n}-9$ & 11.34 & 2.31 & n.s & $3.17 \pm 2.54$ & $12.57 \pm 4.92$ & $*$ \\
\hline Ratio & & & & & & \\
$\sum \mathrm{n}-3 / \sum \mathrm{n}-6$ & $6.14 \pm 0.66$ & $6.01 \pm 0.27$ & n.s & $6.38 \pm 0.51$ & $6.05 \pm 0.29$ & n.s \\
PUFA/SFA & $1.12 \pm 0.09$ & $1.14 \pm 0.06$ & n.s & $1.39 \pm 0.02$ & $1.20 \pm 0.05$ & $*$ \\
DHA/EPA & $2.25 \pm 0.66$ & $3.62 \pm 0.91$ & $*$ & $1.01 \pm 0.05$ & $1.06 \pm 0.08$ & n.s \\
ARA/EPA & $0.14 \pm 0.02$ & $0.19 \pm 0.01$ & $*$ & $0.19 \pm 0.14$ & $0.31 \pm 0.25$ & n.s \\
DPA/ARA & $0.55 \pm 0.03$ & $0.52 \pm 0.01$ & n.s & $0.33 \pm 0.37$ & $0.28 \pm 0.30$ & n.s \\
\hline
\end{tabular}

